\title{
Reflections on Microscopy and Analysis: From Viewing the Small World to Leading on a Larger Stage
}

\author{
David B. Williams
}

Published online: 23 February 2012

(C) Springer Science+Business Media, LLC and ASM International 2012

It is an extraordinary honor to receive the Henry Clifton Sorby Award of the International Metallographic Society (IMS). I am humbled to be included in a list of Sorby Awardees that includes two giants who paved the way in my own field of X-ray analysis in electron-beam instruments: Raimond Castaing and Peter Duncumb. I am delighted to be added to the list that includes two of my early mentors and teachers in Cambridge, Brian Ralph and Robert Honeycombe. I will celebrate the award when I have the chance to raise a glass with my good friends and earlier Sorby awardees, Gareth Thomas, Joe Goldstein, George VanderVoort, and Arlan Benscoter.

Sorby has been described as "The greatest scientist that Sheffield has ever produced", which those of us from neighboring Leeds would view as being damned with faint praise. Sorby invented the science of metallography in 1864. He started by pioneering the microscopy of meteorites and invented the "Spectrum Microscope". As I mentioned, I was raised in Leeds, a scant 30 miles north of where Sorby first practiced metallography. Much of my microscopy career has involved metallography of meteorites and various aspects of spectrometry in the (electron) microscope. So, given these parallels, perhaps there is some method to the IMS Awards Committee's madness in my nomination.

The Award recognizes "a lifetime (of) achievement", which is a rather daunting thought, and prompted me to

This article is based on the Sorby Lifetime Achievement Award Lecture, IMS Meeting, Nashville, TN, August 8, 2011.

D. B. Williams $(\bowtie)$

College of Engineering, The Ohio State University,

Columbus, OH, USA

e-mail: williams.4219@osu.edu think what I might have gleaned from my "lifetime" in the field that would be worth passing on. First and foremost, right now is the time to acknowledge that this award reflects my great good fortune in working with students and colleagues who are far more talented than me. Growing such a network has been the greatest fun in my professional life.

So, to those younger members of the audience, let me emphasize this primary point. Always say thank you. No one ever receives an award such as this, based solely on his own merits. Start early in your career by thanking the students in your labs and lectures. If you've done your job well, by the time you reach my age, some of those students will be the providers of funding for your research, suppliers of instruments for your labs, your entree into partnerships with major companies, other universities and national labs, and the source of new employment opportunities for you-and your colleagues. I have experienced all of the above. So start networking at the earliest opportunity. Electronic communications media make this task so much easier than the handwritten letters and land-line phone calls, which were for me the only way to network, apart from professional conferences. So use LinkedIn, Plaxo, and Facebook. Use this technology to your benefit—network, network, network!

It's worth taking stock of how I reached the point where my cumulative accomplishments were enough to merit this award. By some standards, I have had a successful career; as a microscopist, as a professor of materials science, and as a university administrator. If I were to present a condensed history of these careers, they would be summarized as follows:

- I became a scientist because I failed an English literature exam as a 16-year old, and thus flunked out of my first career choice-to study geography. 
- I became a metallurgist because I was ejected from physics after my first year at Cambridge, thus failing my second career choice of becoming a particle physicist.

- I failed to find a job after my BA so I stayed on for a Ph.D.

- I learned to operate electron microscopes because my first choice for a Ph.D., to study rapid solidification, ended before it began when the professor with whom I wished to work told me he had enough students. So I knocked on the next office door, a young director of research, Jeff Edington, welcomed me in....and the rest is history.

- I had educated myself out of a job in the UK after my Ph.D. so I spent 6 weeks in Australia where I found my wife, but no job. My next trip was to the USA where a $\$ 12$ bus ride from the Port Authority of NYC to Bethlehem, PA, saw me interviewed and hired at Lehigh as an assistant professor in physical metallurgy.

- I became an "expert" in transmission electron microscopy (TEM) because no- one at Lehigh could run the electron microscope.

- I became Director of the Electron Microscope Lab at Lehigh because Joe Goldstein became Associate VP for Research.

- I became Department Chair because it was my turn to step up.

- I became Vice Provost for Research because I complained that Lehigh didn't have one. And so on.

A successful career built on a series of failures, a successful career made by stepping into an open door when another closed; seizing opportunity is one road to success. There are many others, but none better than learning about yourself through the management of failure. If you have never failed, you have never pushed yourself.

For most of my academic life since 1980, I have found myself assuming various levels of administration; from running a lab, to leading a department, to being a VP for research, a university president, and now a dean of engineering. Given that barely a handful of electron microscopists have had a career that includes leading a research university, let me use this opportunity to pass on some thoughts that may benefit the younger materials scientists as they set out in their careers. These thoughts are both from the bright-field side of microscopy and the dark-field side of administration. Let me start with five points about microscopy in particular-and any academic career in general:

1. Pick your area of excellence and stick to it. You must have a perceived area of strength for your own good and for your chance to network with others. Technically, it is more difficult now to become a well- recognized expert in a relevant field because there are several dozen TEM fields compared with a half a dozen or so when I started my Ph.D. But the same caveats apply:

- You rarely succeed just by being a microscopist.

- So apply your chosen technique(s) to solve problems in a broader field.

- Make sure that your chosen expertise has sufficient stamina and will not be irrelevant in 5 years; insightful prophecy never goes amiss.

- If you do become well recognized, be sure that others care about it. It's not much use being the best in the world if nobody notices.

This latter point is important because chairs, deans, and others support those who are successful; it's easier to fertilize a flower than to plant seeds and hope for growth. In a time of limited resources, you receive more return on an investment if you invest in success.

2. Pick your colleagues and students carefully. Pick the best in whatever area you chose to work. Make sure they complement your skill-set, and together you can solve problems that you cannot solve alone.

This latter point is also important because chairs, deans, and others understand that the best research advances are usually made by teams. All the fun, and much of the money, is at the interfaces between different techniques and between different disciplines.

3. Do your groundwork. For example, in TEM, the specimen is more important than the instrument. You can do great work with an average microscope if your specimen is great, but you cannot do great work with a great microscope if your specimen is average.

This step is important when you approach your chair, dean, or other administrators for money for a new microscope:

- Never go into the meeting without doing your groundwork.

- Never ask for something without bringing something to the table.

- Never give the other side a chance to say "No".

- Remember: you are not given what you deserve; you receive what you negotiate.

4. Show up to meetings. Busy people rarely read all the papers; there are just too many. Those leaders may recognize your name if you are particularly prolific but if they meet you personally at a meeting they will more likely remember you. But do more than show up; volunteer for committees, become part of the societies and the meetings. Give back, don't just take.

5. It's all about sales and marketing. Every time you talk, you are selling yourself and your ideas. 
- Make sure your conference talks are well prepared; no more than 20 slides, no more than $20 \mathrm{~min}$, and no smaller than 20 point font. Scale up or down accordingly

- It's better to deliver one good point several times than to deliver several points only once. A mediocre idea well presented always beats out a great idea poorly presented.

- So hone your oral and written communications. Practice your "elevator talk". (This is a phrase from the start-up company jargon that refers to an entrepreneur finding herself in the elevator with a venture capitalist. She has $30 \mathrm{~s}$ to get his attention-and his money).

- When you have a chance to bend the ear of your chair, dean, VPR, your program manager at the federal agency, the journal editor, or anyone else who affects your life, make sure that they remember you-and your pitch.

- Make any pitch short, relevant, and ensure it contains no acronyms or words of more than three syllables.

Let me broaden the stage from microscopy by saying a few words about five major issues that I see facing young scientists/engineers today:

1. The peer review system is seriously compromised. There are too-few qualified reviewers asked to review too many unqualified papers. If anyone thinks the peer review system is fair, then you don't know how it works. If anyone thinks it's the worst system, I would argue that we do not have the evidence to make this statement; we have tried so few others. If we want a fair review system, let's remove all names and affiliations, cross references, and history of prior work. Let the initial review of any paper be based on (no more than five pages) of the technical context, results, and brief discussion. Once it passes this technical review, then initiate a review with all the details. Until we free papers from the control of the publishing industry, this will not happen.

2. Should we continue to support traditional journals? There are many opportunities to publish, and across such a range of quality that anyone can have anything published. I have played a role in this and have my share of publications with no citations. As I mentioned earlier, too many papers mean that few people are able to keep up with their field. Or, to look at the situation another way, too much time is wasted reading too much material with little or no contribution to existing state-of-the-art.

- When publishing houses can take a single highquality scientific journal, split it into many journals and proclaim to maintain the same quality, then I think the system is broken.

- When scientific journals can make science news rather than publish the data, then we have the equivalence of Rupert Murdoch in our midst.

- When our intellectual property is copyrighted by the journals and WE pay for OUR IP to be published, and the publishers then stand aside while our IP is available for download by whomever wants to steal it, then the publishing system is broken (Google "Free download Williams and Carter" to see what I mean).

- Perhaps Apple can do to the publishing industry what it has done to the music industry and restore the control of the publications to the scientists who produce them and to the scientists who read them.

3. The traditional model of research funding via the federal agencies is increasingly less viable. There are too many researchers chasing too few dollars; too much expected of those who get increasingly less dollars to do more. I would like to put forward the same system for proposal reviews as for technical papers. Should those who have a proven career of success have to continue to jump through the same hoops as those who have no track record? In other words, while we rightly offer significant opportunities for "early career funding", should we not also offer a separate category for "established or late career funding", with of course the same caveat about peer reviews?

4. Should funding agencies demand a measurable return on their investment? Should the traditional funding agencies take a leaf out of the books of the missiondriven agencies such as DARPA and the companies that fund industrially-driven research? I believe that industrial problems can be as intriguing and challenging as any blue-sky research and currently are much easier to fund. Companies are sitting on trillions of dollars as they wait out the economic uncertainty; uncertainties that are not going to go away for many years and thus will dominate the funding landscape. One option is to spread the wealth and engage in public-private research partnerships between tradition agencies and corporations, such as the NSF IUCRC model. The driving force for such funding will increasingly be tied to the long-term economic problems of the western world, and job creation will be one of those drivers. It is our research that has to be the economic driver.

5. In today's world the days of the single-author paper or the single-investigator proposal are numbered. So join 
the big groups that can address the big problems: energy, health, transportation, global climate change, food security, information assurance. Because of this change in opportunities and expectations, we collectively have to find ways to assess the progress of young professors in ways that are different from the processes by which our success was evaluated.

So let me summarize the lessons herein:

- Failure can be the best lesson. If you've never pushed the envelope, you've never found your limits.

- Find what you like and do it better than anyone else. It has to be fun to stay in the office/lab late at night and on weekends.

- Know your field and make sure you are relevant, and be prepared to change as your fields change.

- Become involved; when doors open, go through them. Say "yes" all the time (to reasonable requests). Once you start saying "no", people will stop asking. Volunteer to be on committees, show up at meetings.

- Market your work unceasingly. It's all about sales and marketing. Speak at every event you can, and make sure your talks are good. Make one point and make it well.

- Network, network, network, at all stages of your career. Pick your advisor, pick your colleagues, pick your students, treat them all well and give everyone else the credit.
Many challenges face the next generation of microscopists, scientists, and engineers along with the deficit, climate change, overpopulation, and multiply-resistant bacteria. But before you think it's all bad, let me quote from Tony Capstick, whose most famous song "A Sheffield Grinder" celebrated those men who made their living (and often met their death) grinding knife blades from the same steel that Sorby first studied. "We'd lots of things in them days we 'aven't got today-rickets, diphtheria, ringworm...thou doesn't know tha's born".

So my talk returns to Sheffield and to Henry Clifton Sorby, a true amateur scientist and microscopist (not that he wasn't paid to do microscopy, he could afford not to be paid). Sorby donated some of his wealth to his local university. The name of Sorby is perpetuated not just in this IMS award but in the Sorby Chair (formerly of Geology, now Earth Sciences) at the University of Sheffield, the Sorby Research Fellowship of the Royal Society, and the Sorby Society of Sheffield.

This is the last lesson: as you go through your professional life and reflect on the opportunities that have been given to you by others: be prepared to give to those less fortunate than you so that they may have the chance to achieve what you have done. And in particular, open doors for your students in the same way that doors were opened for you.

Thank you.

David B. Williams 